\title{
BMI1 and KAP1 interaction and function: BMl1 capped by KAP1?
}

\author{
J. van Haasteren \\ Department Molecular Genetics, GROW School of Oncology and Developmental Biology, \\ Maastricht University \\ j.vanhaasteren@student.maastrichtuniversity.nl
}

\section{Abstract}

The Polycomb-repressive complex 1 ( $\left.\mathrm{PRC}_{1}\right)$ protein $\mathrm{BMl}_{1}$ is of major importance in the epigenetic regulation of gene expression. The repression of important tumour suppressor genes (such a P16INK4a and P14ARF) by means of chromatin remodeling has marked BMl1 as a proto-oncoprotein. We previously found evidence that posttranslational modification by phosphorylation may be implicated in the stability and functioning of BMl1. Furthermore, we found that KAP1, through direct interaction with BMl1, may be implicated in regulation of BMl1 functioning. I here begin to elucidate how phosphorylation affects BMl1 and how KAP1 regulates BMl1. Several $\mathrm{U}_{2} \mathrm{OS}$ or $\mathrm{TIG}_{3} \mathrm{ER}$ cell lines were created that overexpressed BMl1 wild type and mutants that either contain phospho-mimic or phospho-null mutations. shRNA's were used to effectively knockdown KAP1 expression. The effect of BMl1 mutant overexpression and/or KAP1 knock down on proliferation was measured under cell stress conditions induced by arsenite, selenite or etoposide. The effect of KAP1 knock down and mutant KAP1 lacking the RingFinger domain (KAP1-DeltaRF) on sub-cellular localization was assessed in $\mathrm{U}_{2} \mathrm{OS}$ cells. Finally functional interaction between $\mathrm{KAP} 1$ and $\mathrm{PRC} 1$ was measured by analysis of transcriptional induction of the PRC1-target gene ATF3 upon mitogenic stimulation. BMl1 overexpression partially rescues arsenite induced senescence; this rescue activity is affected by its phosphorylation status. KAP1 knockdown increases the effect of BMl1 overexpression on proliferation under arsenite induced cell stress but ablates the differences observed between different BMl1 phospho-mutants. KAP1 induced increases of ATF3 induction point towards a functional interaction between KAP1 and $\mathrm{PRC}_{1}$. My experiments provide experimental indication that BMl1 affects proliferation under arsenite induced cell stress condition. This effect was enhanced by KAP1 knockdown suggesting that KAP1 inhibits the pro-proliferative effects of BMI1. Increased ATF3 induction in the presence of KAP1-DeltaRF mutant protein 
suggests that the KAP1 negatively controls expression of ATF3 in a RF-dependent manner. Further research is required to elucidate the exact molecular mechanisms underlying the function interaction of BMl1 and KAP1.

\section{Keywords}

Polycomb group proteins, Polycomb repressive complex, BMl1, KAP1, RingFinger domain, gene repression.

\section{Introduction}

Polycomb group (PCG) proteins function is of paramount importance in epigenetic regulation and the propagation of heritable epigenetic mark-up throughout cell division. With this in mind it is perhaps not surprising that PcG proteins are involved in embryonic development, differentiation and (stem) cell fate, and the aetiology of cancer (1-3). Polycomb proteins are present in several protein complexes, the two main ones being Polycomb repressive complex 1 and 2 (PRC1 and PRC2) (4). These multiprotein complexes exist in varying compositions of Polycomb proteins between cell types (5) and the function of the complex alters according to its composition (6). As the name implies, PRC1 and 2 contribute to the repression of gene expression. They do so by chromatin remodelling via histone modification. Indeed, a number of the functions of PRC's involve the addition and removal of chemical groups to histone tail residues. In the process of gene silencing, it is PRC2 that functions first by adding a third methyl group to lysine 27 of histone 3 ( $\mathrm{H}_{3} \mathrm{~K}_{27} 7-$ me3) (7). On recognition of $\mathrm{H}_{3} \mathrm{~K}_{2} 2-\mathrm{me}_{3}$, the $\mathrm{PRC}_{1}$ complex functions as an $\mathrm{E}_{3}$ ubiquitin ligase and ubiquitylates lysine 119 of histone $2 \mathrm{~A}\left(\mathrm{H}_{2} \mathrm{AK} 119-\mathrm{Ub}\right)(8,9)$. It is this ubiquitylation that causes repression of gene expression (figure 1).

BMl1 is part of the PRC1 protein complex in which it occupies a central position, both structurally and functionally (9). BMl1 consists of several functional domains (figure 2). BMl1 in itself has no E3 ligase activity but has been proposed to stimulate the ability of Ring1a and Ring1b to ubiquitylate its targets (9). a recent paper has proposed BMl1/ Ring1a as a potential E3 ligase for topoisomerase $2 a$ (TOP2A) and subsequent targeting for proteolytic degradation (10). Our lab has provided a functional context for the link between $\mathrm{TOP}_{2} \mathrm{~A}$ degradation and BMl1 expression in the context of chondrogenic differentiation (Spaapen et al., submitted). This notion provides ground of further investigation in the mechanisms of anti-cancer drugs that target TOP2A in the context of BMl1 functioning. Besides that, BMl1 has been implicated in ATM-dependent DNA damage repair and it was suggested that BMl1 can be seen as an early DNA damage response (DDR) protein (11).BMl1 is also a potent proto-oncoprotein, as overexpression causes tumours growth by aberrant 
inhibition of the tumour suppressor gene CDKN2A coding for p16INK4a and p14ARF (12, 13). Our lab has recently found evidence for a physical interaction between the Polycomb protein BMl1 and the transcriptional repressor Krüppel-associated-box (KRAB)-associated protein 1 (KAP1) (Prickaerts et al., in preparation). We obtained evidence that shows KAP1 may target $\mathrm{BMl} 1$ for proteasomal degradation, a process which is likely dependent on the RingFinger domain of KAP1 (figure 2). We hypothesized that KAP1 may controls PRC1 functioning via degradations and may as such influence the expression of PRC1 target genes such as ATF3. $_{3}$

To provide context to the how and where of BMl1 activity, potential phosphorylatable BMl1 amino acid residues were identified and mutated to provide insight to the effects of either constitutive phosphorylation or ablation of phosphorylation $(14,15)$. We assessed the effects of these mutations by measuring proliferative capacity of $\mathrm{U}_{2} \mathrm{OS}$ ant $\mathrm{TIG}_{3}$ cell lines during cell stress. Taking previous research into account, we expect that phosphorylation of amino acid residues of BMl1 in the PEST-domain might make it a target for degradation, thereby effectively reducing the positive effect on proliferation $(15,16)$. We hypothesize that post-translational modification of BMl1 by means of phosphorylation will negatively affect its ability to promote proliferation. If BMl1 indeed positively regulates cell proliferation and we take into account our preliminary findings that suggest that KAP1 targets BMl1 for degradation, we anticipate that the loss of KAP1 might synergistically influence the proliferative capacity of cells overexpressing BMl1. The ability to degrade BMl1 might cause $A_{T F}$ to be differentially expressed between KAP1 knockdown and overexpressed cells, and may be altered in a RingFinger dependent manner. This also predicts that KAP1 may affect the association of BMl1 with chromatin.

The implication of $\mathrm{BMl} 1$ and its constituent complex $\mathrm{PRC} 1$ in tumour development make way for targeted anti-cancer therapies. Since the targets of BMl1, p16INK4a and p14ARF, are downregulated in overexpression and may as such stimulate proliferation, inhibition of BMl1 seems a promising possibility for novel cancer therapies. As such, the notion that KAP1 interacts and targets $\mathrm{BMl} 1$ for degradation, thus inhibiting its functioning, makes KAP1 a valid objective for further research. 


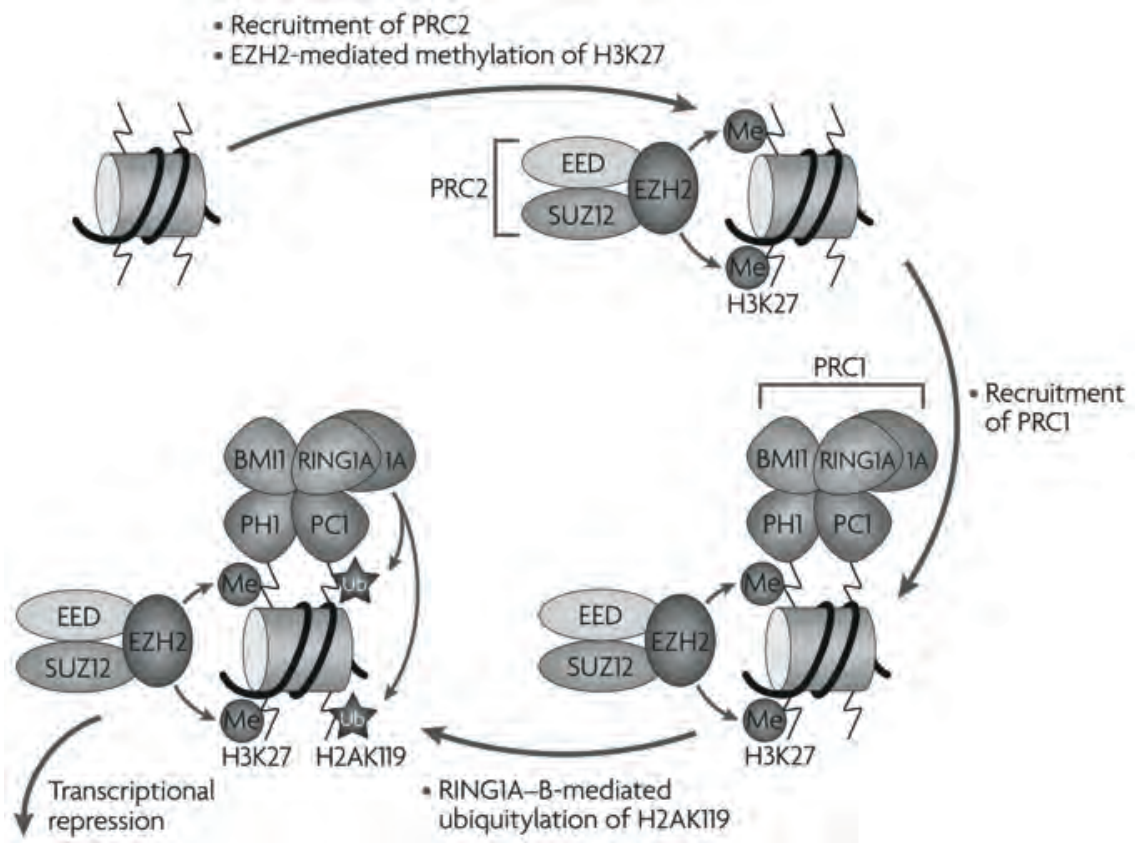

Figure 1. Mechanism of Polycomb repressive complex gene repression. After Polycomb repressive complex 2 (PRC2) is recruited to the DNA, one of the components of PRC2, Enhancer of Zeste ( $\left.E Z \mathrm{H}_{2}\right)$, will methylate histone 3 on lysine 27. In response this mark draws PRC2 to the chromatin, which ubiquitylates the lysine 119 residue of histone $\mathrm{H}_{2} \mathrm{~A}$ to provide robust transcriptional gene repression. Adapted from (17).

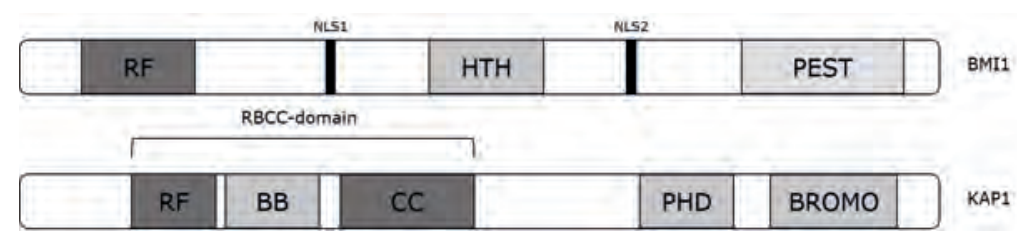

Figure 2. Schematic representation of structure and functional domains of BMl1 and KAP1. BMl1 (top) comprises or three core being a RingFinger domain (RF), a helix-turn-helix motif (HTH) and a proline, glutamic acid, serine and threonine rich domain (PEST). Is also contains two nuclear localisation sequences (NLS1 and NLS2). KAP1 (bottom) encompasses 5 domains, among which a Plant Homeo domain (PHD), a BROMO domain and the RBCC domain. The RBCC domain holds a RingFinger domain (RF), two B-box zinc finger domains (BB) and a coiled-coil domain (CC). 


\section{Material and methods}

Ecotropic and amphotropic vectors were used to efficiently and stably overexpress wildtype or mutant BMl1 or KAP1 protein. Knockdown of KAP1 was performed with shRNA's targeting mature KAP1 mRNA or the 3'UTR region of early mRNA. The latter shRNA provided the opportunity to do a knockdown-add back experiment where endogenous $\mathrm{KAP}_{1}$ could be replaced with mutant KAP1 expression. Experiments were conducted in human osteosarcoma cells ( $\mathrm{U}_{2} \mathrm{OS}$ ) and human primary fibroblast cells ( $\left.\mathrm{TIG}_{3}\right)$. Protein determination by western blot was performed on whole cell protein lysates or subcellular fractions obtained by differential extraction. Proliferation of cells in culture was assessed by means of X-tal Violet staining procedure and subsequent absorbance measurement. Measurements was done at 0, 2, 4 and 6 days post stimulation. Mitogenic stimulation was done with $15 \%$ serum and $0.1 \mu \mathrm{g} / \mathrm{ml}$ tetradecanoyl phorbol (TPA, Sigma) after 48 hour serum starvation. ATF3 mRNA was acquired by RNA isolation using Tri-reagent (Sigma) and subsequent cDNA production by means of the iscript cDNA synthesis kit (Biorad). Quantitative measurement was obtained by RT-PRC analysis where samples were normalized to Cyclophillin A, a housekeeping gene.

\section{Results}

\section{BMl1 overexpression provides protection against arsenite induced senescence}

To examine whether BMl1 offered growth advantage under normal conditions and in situations of cell stress, we generated several cell lines overexpressing wildtype or mutant BMl1. Substitution of 7 key amino acids that were proposed as phosphorylaiton targets were substituted with alanine (7XA) to create a phospho-null mutant whereas a substitution with glutamic acid (7XE) created a phospho-mimic mutant. A BMl1-wild type overexperssion cell line was used as control. Expression of the mutated proteins was comparable, but the expression of the wild-type was over $70 \%$ higher compared to the mutants (unpublished data). We followed cell proliferation over time and plotted the data in growth curves (figure 3 ) We used different conditions, one with the cells embedded in growth medium alone as control (fig $3 \mathrm{~A}$ ) and cell stress conditions consisting of growth medium supplemented with $4 \mu \mathrm{M} / \mathrm{ml}$ sodium arsenite or $4 \mu \mathrm{M} / \mathrm{ml}$ sodium selenite (figure $3 \mathrm{~B}$ and $\mathrm{C}$ respectively). While no difference in growth rate could be observed in the control condition (fig. 3A), BMl1 overexpression has a marked effect on the proliferation of $\mathrm{U}_{2} \mathrm{OS}$ cells when subjected to cell stress. When stressed with $4 \mu \mathrm{M} / \mathrm{ml}$ sodium arsenite (As), BMl1 overexpression attenuates the As-induced proliferative arrest observed in the $\mathrm{U}_{2} \mathrm{OS}$ control cells. The effect is most evident in the BMI-7XE cells, suggesting that phosphorylation of 
BMl1 positively contributes to protection or proliferation of As-exposed cells. The positive effect of BMI-2PY 7XA on proliferation is less than that of the BMl1 wild-type. Although this data suggests that the ability to be phosphorylated is paramount in the functioning of BMl1, this effect can also be ascribed to the differences in protein levels compared to wild-type BMl1.

\section{KAP1 knockdown increased BMl1 induced resistance to arsenite induced senescence}

In order to assess the influence of KAP1 on cellular proliferation under both normal and cell stressed conditions we infected cell lines with short hairpin RNA's (shRNA's) to create knockdown of KAP1. shRNA targeting green fluorescent protein (shGFP) was used as control as U2OS cells do not express GFP. KAP1 and GFP knockdown was performed in BMl1 mutant (7XA and 7XE) and wild type overexpressing cells. Cells were subjected to different cell stressors and relative cell number was followed over time to create growth curves indicative of proliferation rate.

The loss of KAP1 in BMl1 mutants had no significant effect in control conditions of plain growth medium (figure $4 \mathrm{~A}-\mathrm{D}$ ). Loss of $\mathrm{KAP} 1$ in itself does not provide protection against arsenite induced cell stress, however, all BMI constructs in our model do (figure $4 \mathrm{~F}-\mathrm{H}$ ). In addition, loss of KAP1 provides an additional proliferative advantage in combination with all BMl1 constructs; this suggests a cooperative effect under arsenite-stressed conditions. Plotting the same data in graphs combining the BMl1 mutants, BMl1 wild-type and control cell lines all with KAP1 knockdown suggested that loss of KAP1 reduces the differences that were found in cells that do indeed express KAP1 (figure 5). Etoposide affects shKAP and shGFP cells equally, suggesting KAP1 depletion does not provide protection (figure 4l). Under these conditions BMl1 overexpression does not provide substantial protection, as proliferation with or without BMl1 overexpression remains unaltered. BMl1-WT and 7XA in combination with shKAP however show a slight proliferative advantage.

\section{RingFinger domain required for KAP1 mediated changes in ATF3 expression}

Next, we set out to assess the influence of KAP1 on PRC1 functioning. ATF3 was shown to be a target of $\mathrm{PRC}_{1}$ but not of KAP1 (18). We therefore measured $A \mathrm{TF}_{3}$ induction in response to mitogenic stimulation to assess a possible effect of KAP1 on PCR1-mediated gene repression. Measuring ATF3 in the presence of wild-type full length KAP1 (KAP1-fl) or a KAP1 mutant missing the RingFinger domain (KAP1-DeltaRF), will enable us to provide insight into the effects that KAP1 has on PRC1 function and whether the RingFinger domain of KAP1 is involved. KAP1 was first knocked down with 3'UTR shKAP1 and Flag-tagged exogenous KAP1 was added back. A viral vector expressing Flag only was used as a control (NLS-Flag). 
All cell lines show a transient induction of ATF3 post-serum/TPA stimulation (figure 6). shKAP1eV (NLS-Flag) cells showed an attenuated transcriptional response in comparison to cells expression shKAP1/KAP1-fl, as evidenced by a lower relative ATF3 induction. However, since ATF3 is not a KAP1 target (19), this response is expected to be indirect. This result is in concordance with its proposed repressive effects of KAP1 on BMl1. Loss of KAP1 would increase BMl1 levels, thereby increasing ATF3 gene repression by PRC1 and thereby decreasing its expression. Conversely, the overexpression of a KAP1 mutant lacking the RingFinger domain elicited a greater response than wild-type KAP1.
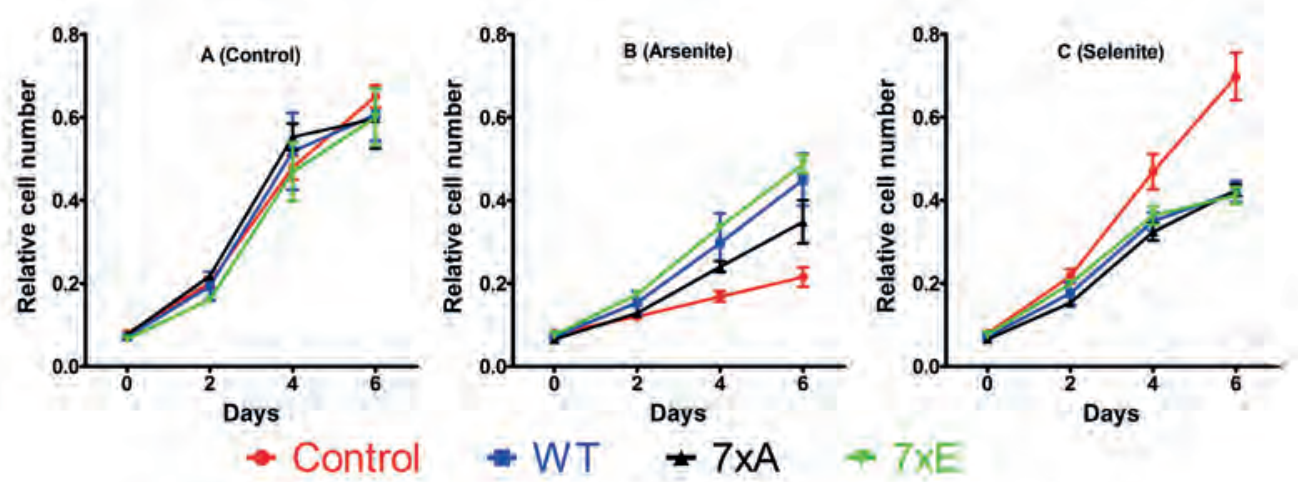

Figure 3. Phospho-mimic mutant BMl1 overexpression attenuates senescence by arsenite poisoning. Growth curve analysis of $\mathrm{U}_{2} \mathrm{OS}$ stably overexpressing BMl1 mutant protein. (A) U2OS cells cultured in plain medium. (B) $U_{2} \mathrm{OS}$ cells cultured in medium supplemented with $4 \mu \mathrm{M} / \mathrm{ml}$ sodium arsenite show different proliferation rates between cell lines expressing different BMI1 mutants. Greatest effects are observed in wild-type BMl1 and phosphor-mimic BMl1 mutant. (C) Stimulation of $\mathrm{U}_{2} \mathrm{OS}$ cells stably expressing exogenous BMl1 with $4 \mu \mathrm{M} / \mathrm{ml}$ sodium selenite. Exogenous BMl1 expression attenuates proliferation in comparison with control U2OS cells. 


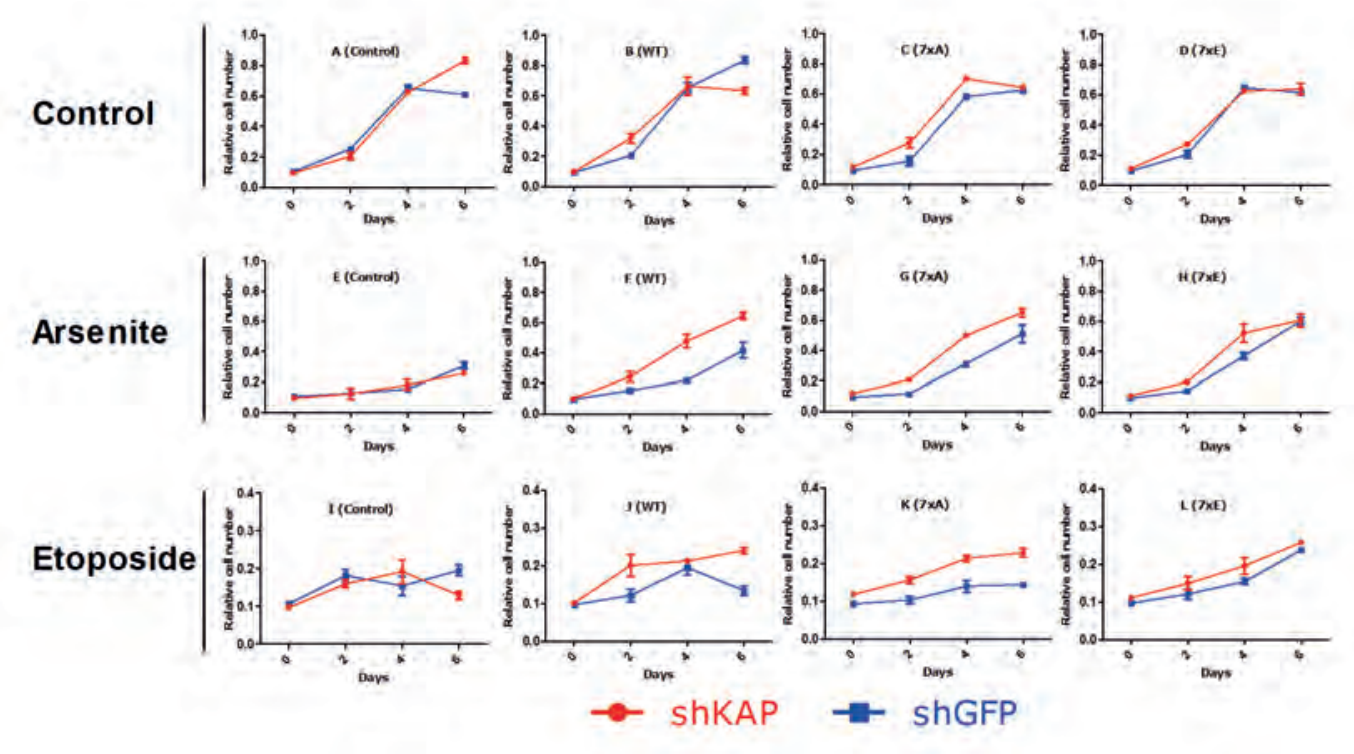

Figure 4. KAP1 knockdown increased BMl1 mutant overexpression induced changes in proliferation under arsenite and etoposide induced cell stress. Relative cell numbers indicate no change in proliferation in control situations between shKAP1 and shGFP cell lines in all BMl1 variants. KAP1 knockdown increased proliferation in BMl1 overexpressing cells under arsenite induced stress (F-G) and the 7XA BMl1 mutant proved to proliferate more rapidly under etoposide stress conditions when $\mathrm{KAP} 1$ is knocked down.

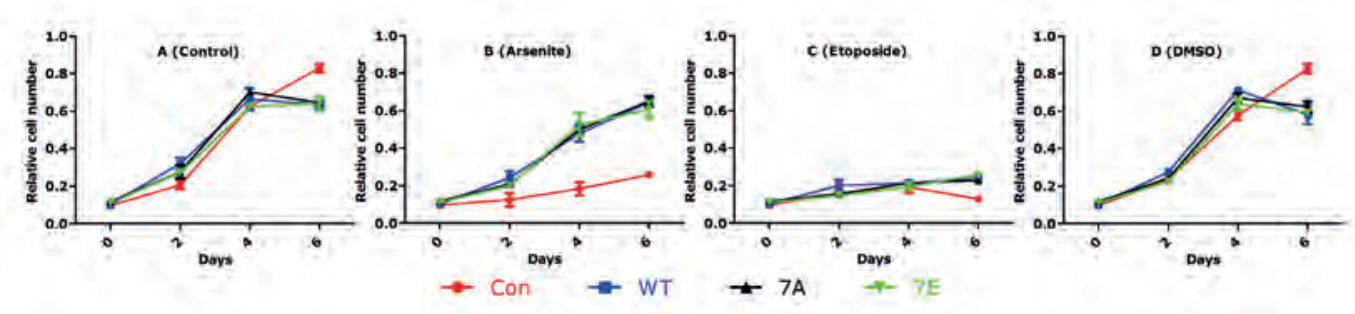

Figure 5. KAP1 knockdown in BMl1 mutant U2OS cells diminished differential effects between mutants. KAP1 knockdown was achieved with shKAP1 infection. The same cell lines were used as in figure 4 but the knock down of KAP1 proves to reduce the differences between BMl1 mutants we saw in proliferation under arsenite stimulation.

It is of interest, to observe that the ATF3 induction dynamics shows a premature induction and a delayed shut down in the presence of KAP1-dRF, in comparison to KAP1-fl. The 
enhancement of $\mathrm{ATF}_{3}$ induction in the presence of a $\mathrm{KAP1} 1 \mathrm{RF}$ mutant was surprising, as previous results suggested that the RingFinger domain is required for KAP1 mediated degradation and that KAP1 may control repressive action by PRC1 through inducing proteolytic degradation of BMl1. Combined, the above data suggests that KAP1 control initiation of transcription as well as silencing. Whether both properties involved KAP1BMl1 interaction is currently not clear. It is currently also not possible to conclude whether $\mathrm{KAP} 1$ targets $\mathrm{BMl}_{1}$ and thereby $\mathrm{PRC}_{1}$-mediated repression, through RF-mediated $\mathrm{E}_{3}$-ligase activity, or whether it is the physical presence of $\mathrm{KAP} 1$, that through its RF domain recruits additional E3-ligase activity which targets BMl1 for degradation.

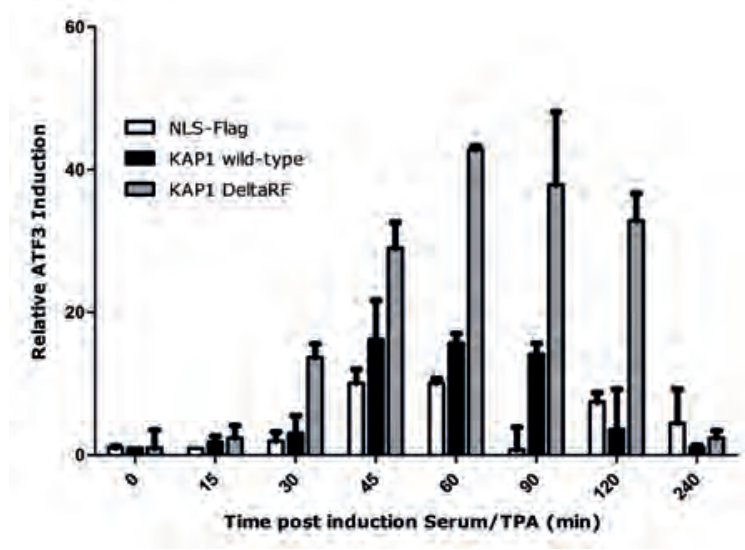

Figure 6. ATF3 expression increase following serum/TPA stimulation increased by loss of RingFinger domain of KAP1. The expression levels of PRC1 target gene ATF3 as measured by rTPCR and normalized to cyclophillin A are provided as relative induction compared to control situation $(t=0)$. Double $3^{\prime} U T R$ shKAP1 infected U2OS cells were infected with either NLS-Flag (control), full-length KAP1 or KAP1 delta-RingFinger viral vector to stably induce expression of these proteins (supplemental figure 5). Restoring KAP1 increases the transcriptional response measured as ATF3 induction. KAP1 DeltaRF shows a greater response compared to wild-type KAP1.

\section{Chromatin association of KAP1 and BMl1 in response to mitogenic stimulation}

To provide more insight into the molecular details in KAP1/BMl1 interaction in the context transcriptional regulation, we examined the subcellular localisation of KAP1 and BMl1 post-mitogenic stimulation. By means of differential fractionation, we were able to analyse the cytoplasmic, soluble nuclear and chromatin bound protein fractions in U2OS cells. We again used 3'UTR KAP1 knock down U2OS cells to reintroduce Flag tagged wild- 
type KAP1 and a mutant lacking the RingFinger domain (Flag-KAP1 DeltaRF). Cells infected with an empty vector construct (NLS-Flag) were used as controls. KAP1 and BMl1 protein were visualized by western blot in the different subcellular fractions.

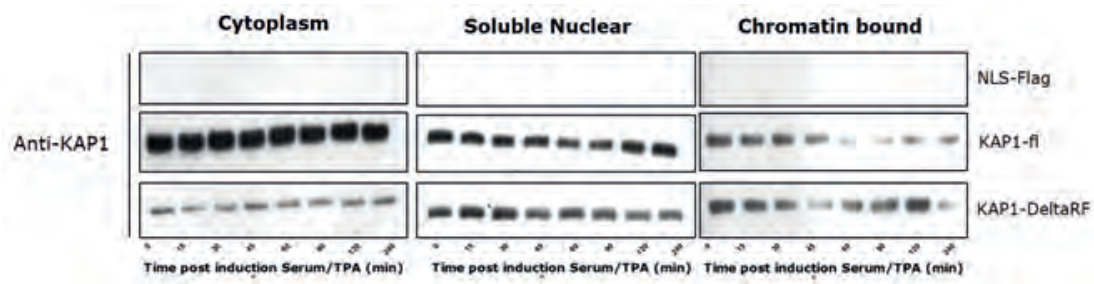

Figure 7. Serum/TPA induced mitogenic stimulation changes subcellular localisation of KAP1. Protein lysates of cytoplasmic, soluble nuclear and chromatin bound fractions visualised are using western blot. KAP1 is removed from the chromatin fraction at 60 minutes post mitogenic stimulation for wild-type KAP1 and 45 minutes in the case of KAP1-DeltaRF. Chromatin localisation of KAP1 is restored around 1 hour later.

Due to unfortunate problems with the secondary antibodies targeting monoclonal primary antibodies in our lab, we were only able to visualise the expression of KAP1 (which is detected using a polyclonal primary antibody). Since the loading controls cannot be used to prove equal protein loading, we cannot be certain about the KAP1 levels in the different cellular compartments. Taking this into account we can however cautiously interpret the data at hand (figure 7). The findings suggest that KAP1-fl dissociates from chromatin around 60 minutes post-serum/TPA stimulation and is recruited to chromatin after 120 minutes. Remarkably, KAP1-DeltaRF dissociation dynamics are substantially altered: KAP1-DeltaRF dissociation is transient and recruitment of KAP1-DeltaRF is more profound compared to KAP1-fl. Taken together, RF-mutation clearly affects KAP-1 chromatin-binding dynamics and PCR1-mediated gene repression.

\section{Discussion/Conclusion}

In this study we provided experimental data that begins to explain BMl1 functioning in cell proliferation and provides clues to the functional implications of KAP1/PRC1 interaction. We have discovered that in the presence of arsenite stimulation, BMl1 overexpression is able to protect $\mathrm{U}_{2} \mathrm{OS}$ cells against the induced cell stress and partly restore cell proliferation (figure $3 \mathrm{~B}$ ). In our model of BMl1 phospho-mutants, the most profound effect was found in the mutant protein that had phospho-mimicking substitution mutations applied to amino acids that were rendered functionally important as phosphorylation targets. This suggests that phosphorylation of those amino acids is implicated in the functioning of 
BMl1 in arsenite-induced cell stressed conditions. Surprisingly, in cells exposed to selenite BMl1 overexpression seems, regardless of mutation, to decrease the rate of proliferation compared to the control cell line (figure $3 \mathrm{C}$ ). We know that in response to DSB induced $\mathrm{H}_{2} \mathrm{AX}$ phosphorylation, BMl1 will ubiquitylate $\mathrm{\gamma}-\mathrm{H}_{2} \mathrm{AX}$ to stimulate the correct DNA damage repair system (11). As selenite induces DSBs, BMl1 overexpression could be expected to rescue the cells by ensuring an adequate DSB repair response and prevent cell death, as was reported before (20), but this appears not to be the case in our experimental setting. Since phosphorylation status does not change the response BMl1 functioning alteration by phosphorylation events cannot be appointed as the cause of this effect. One explanation can be that the overexpression of BMl1 causes a DNA damage response signalling cascade that is so strong that it may push cells towards senescence (21).

Combining KAP1 knock down with BMl1 overexpression proved to produce a significant increase in proliferation in arsenite induced cell stress in $\mathrm{U}_{2} \mathrm{OS}$ cells (figure 4). This synthetic effect implicates a functional interaction between KAP1 and BMl1 on proliferation under cell stress conditions. Our group has previously hypothesised that KAP1 targets BMl1 for degradation in cell stress conditions induced by arsenite and selenite. At first glance, our results fit with this explanation. If $\mathrm{KAP}_{1}$ is not present to inhibit $\mathrm{BMl}_{1}$, the expression of BMl1 is expected to increase. This has to be validated for each BMl1 type in our model. The fact that all three of the used BMl1 varieties show similar proliferative responses in the absence of KAP1 suggests that phosphorylation status of BMl1 is only of importance when KAP1 is present. While this is not conclusive proof, it points toward the notion that at least one of these seven amino acid residues is implicated in the BMl1/KAP1 interaction or other functional relations (e.g. ubiquitylation, degradation).

The results obtained by assessing the induction of ATF3 expression following mitogenic stimulation once again point towards a functional interaction between KAP1 and BMl1 (figure 6). The differences in ATF3 induction between cell lines devoid of KAP1, expressing KAP1 wild-type and KAP1-DeltaRF suggest that KAP1 is implicated in PRC1 functioning. As ATF3 induction is enhanced in KAP1 missing the RingFinger domain, it is possible that these effects are caused by ubiquitylation of BMl1 by KAP1. It is not clear however, whether and how physical presence of KAP1 and/or functional mutation are implicated in transcriptional control in collaboration with PRC1. As KAP1-DeltaRF misses the E3 ligase activity required for the previously hypothesised mechanism of inhibition of BMl1; ubiquitylation and subsequent proteasomal degradation, we propose an indirect inhibition of BMl1 by KAP1. KAP1 can inhibit $p_{53}$ functioning by promoting ubiquitylation of 553 by MDM2, not dissimilar to how BMl1 promotes H2AK119-Ub by Ring1b (23). If KAP1 would be able to inhibit BMl1 through a second protein, we can begin to explain the increase of induction of ATF3 that we observed in the KAP1-DeltaRF cell line. 
Although the results of the subcellular fractionation were inconclusive, we can state that the chromatin localisation of KAP1 is not dependent on its RingFinger domain (figure 7). A possible mechanism could be an auto-ubiquitylation event of KAP1, which would inhibit its function and attenuate co-localisation to chromatin following mitogenic stimulation. The proposed auto-phosphorylation would be abrogated in the RingFinger mutant of KAP1, providing a possible explanation for the observed increase and altered dynamics in chromatin localisation of KAP1-DeltaRF.

We have here demonstrated that the Polycomb protein BMl1 enhances resistance to arsenite induced- proliferative arrest. Furthermore we have provided further indication for a functional KAP1/BMl1 interaction both under cell stress conditions and mitogenic stimulation. While we found indications that phosphorylation status of BMl1 and the RingFinger domain of KAP1 are implicated in this interaction, we cannot provide conclusive evidence on the underlying molecular processes involved. Elucidating the mechanisms by which KAP1 modifies the function of BMl1 and what post-translational modifications of BMl1 are crucial for its function are compelling targets for future research.

\section{Role of the student}

J. van Haasteren was an undergraduate student in Biomedical Science working under the supervision of Dr Jan-Willem Voncken when the research in this report was performed. The topic and experiments were proposed by the supervisor. The design and planning of the experiments, the processing of the results as well formulation of the conclusions and the writing were done by the student.

\section{References}

1. Sparmann A, van Lohuizen M. Polycomb silencers control cell fate, development and cancer. Nature reviews Cancer. 2006;6(11):846-56.

2. Posfai E, Kunzmann R, Brochard V, Salvaing J, Cabuy E, Roloff TC, et al. Polycomb function during oogenesis is required for mouse embryonic development. Genes \& development. 2012;26(9):920-32.

3. Surface LE, Thornton SR, Boyer LA. Polycomb group proteins set the stage for early lineage commitment. Cell stem cell. 2010;7(3):288-98.

4. Francis NJ, Kingston RE. Mechanisms of transcriptional memory. Nature Reviews Molecular Cell Biology. 2001;2(6):409-21.

5. Gunster MJ, Raaphorst FM, Hamer KM, den Blaauwen JL, Fieret E, Meijer CJ, et al. Differential expression of human Polycomb group proteins in various tissues and cell types. Journal of cellular biochemistry Supplement. 2001;Suppl 36:129-43

6. Simon JA, Kingston RE. Mechanisms of polycomb gene silencing: knowns and unknowns. Nature reviews Molecular cell biology. 2009;10(10):697-708.

7. Czermin B, Melfi R, McCabe D, Seitz V, Imhof A, Pirrotta V. Drosophila Enhancer of Zeste/ESC Complexes Have a Histone $\mathrm{H}_{3}$ Methyltransferase Activity that Marks Chromosomal Polycomb Sites. Cell. 2002;111(2):185-96. 
8. Wang $\mathrm{H}$, Wang L, Erdjument-Bromage $\mathrm{H}$, Vidal $\mathrm{M}$, Tempst $\mathrm{P}$, Jones $\mathrm{RS}$, et al. Role of histone $\mathrm{H}_{2} \mathrm{~A}$ ubiquitination in Polycomb silencing. Nature. 2004;431(7010):873-8.

9. Cao R, Tsukada Y, Zhang Y. Role of Bmi-1 and Ring1A in $\mathrm{H}_{2} \mathrm{~A}$ ubiquitylation and Hox gene silencing. Molecular cell. 2005;20(6):845-54.

10. Alchanati I, Teicher C, Cohen G, Shemesh V, Barr HM, Nakache P, et al. The E3 Ubiquitin-Ligase Bmi1/Ring1A Controls the Proteasomal Degradation of Top2- Cleavage Complex-A Potentially New Drug Target. PloS one. 2009;4(12):e8104.

11. Ismail IH, Andrin C, McDonald D, Hendzel MJ. BMl1-mediated histone ubiquitylation promotes DNA doublestrand break repair. The Journal of Cell Biology. 2010;191(1):45-60.

12. Vonlanthen S, Heighway J, Altermatt H, Gugger M, Kappeler A, Borner M, et al. The bmi-1 oncoprotein is differentially expressed in non-small cell lung cancer and correlates with INK4A-ARF locus expression. British journal of cancer. 2001;84(10):1372.

13. Kim JH, Yoon SY, Kim C-N, Joo JH, Moon SK, Choe IS, et al. The Bmi-1 oncoprotein is overexpressed in human colorectal cancer and correlates with the reduced p16INK4a/p14ARF proteins. Cancer letters. 2004;203(2):217-24.

14. Niessen HE, Demmers JA, Voncken JW. Talking to chromatin: post-translational modulation of polycomb group function. Epigenetics \& chromatin. 2009;2(1):10.

15. Voncken JW, Niessen H, Neufeld B, Rennefahrt U, Dahlmans V, Kubben N, et al. MAPKAP kinase 3pK phosphorylates and regulates chromatin association of the polycomb group protein Bmi1. The Journal of biological chemistry. 2005;280(7):5178-87.

16. Yadav AK, Sahasrabuddhe AA, Dimri M, Bommi PV, Sainger R, Dimri GP. Research Deletion analysis of BMl1 oncoprotein identifies its negative regulatory domain. Molecular cancer. 2010;9.

17. Spivakov M, Fisher AG. Epigenetic signatures of stem-cell identity. Nature Reviews Genetics. 2007;8(4):263-71.

18. Bracken AP, Dietrich N, Pasini D, Hansen KH, Helin K. Genome-wide mapping of Polycomb target genes unravels their roles in cell fate transitions. Genes \& development. 2006;20(9):1123-36.

19. O'Geen H, Squazzo SL, lyengar S, Blahnik K, Rinn JL, Chang HY, et al. Genome-wide analysis of KAP1 binding suggests autoregulation of KRAB-ZNFs. PLoS genetics. 2007;3(6):e89.

20. Lu J, Kaeck M, Jiang C, Wilson AC, Thompson HJ. Selenite induction of DNA strand breaks and apoptosis in mouse leukemic L1210 cells. Biochemical pharmacology. 1994;47(9):1531-5.

21. d'Adda di Fagagna F. Living on a break: cellular senescence as a DNA-damage response. Nature reviews Cancer. 2008;8(7):512-22.

22. Burden DA, Kingma PS, Froelich-Ammon SJ, Bjornsti M-A, Patchan MW, Thompson RB, et al. Topoisomerase II. etoposide interactions direct the formation of drug-induced enzyme-DNA cleavage complexes. Journal of Biological Chemistry. 1996;271(46):29238-44.

23. Wang C, Ivanov A, Chen L, Fredericks WJ, Seto E, Rauscher FJ, 3rd, et al. MDM2 interaction with nuclear corepressor KAP1 contributes to $P 53$ inactivation. The EMBO journal. 2005;24(18):3279-90. 